\title{
Place Branding and Urban Regeneration as Dialectical Processes in Local Development Planning: A Case Study on the Western Visayas, Philippines
}

\author{
Christian Nagaynay ${ }^{1}$ and Jeongwoo Lee ${ }^{2, *}$ \\ 1 Department of Urban Development and Policy, Graduate School, Chung-Ang University, Seoul 06974, Korea; \\ xtian.nagaynay@gmail.com \\ 2 Department of Urban Design and Studies, Chung-Ang University, Seoul 06974, Korea \\ * Correspondence: jeongwoo@cau.ac.kr
}

Received: 15 November 2019; Accepted: 30 December 2019; Published: 2 January 2020

\begin{abstract}
Place branding is an emerging concept in urban regeneration strategies. To date, case studies on the link between place branding and urban regeneration have utilized ambiguous terminology and definitions, and often lack empirical and theoretical grounding. Available literature seldom considers the perspectives of government officials and experts, which are critical in terms of policy support and direction. In order to ensure the sustainability of place branding initiatives as core parts of urban regeneration, it will be necessary to engage local development stakeholders. Hence, this study frames place branding and urban regeneration within a dialectic process involving these key actors in the Western Visayas region of the Philippines. Our results indicate sporadic, but pragmatic, perceptions of place branding that are highly focused on slogans and logos. Moreover, the commonality between place promotion and cultural and historical preservation suggests a connection between place branding and urban regeneration. Specifically, flagship construction is the most favored place branding strategy, due to its high-weighted value in terms of applicability, sustainability, and the promotion of local development. The results of this study can serve as the groundwork for policies that will bring place branding and urban regeneration strategies into the mainstream of local development planning, with particular foci on how place branding can strengthen a place's identity and establish sustainable regeneration strategies.
\end{abstract}

Keywords: place branding; urban regeneration; dialectics; local development planning; sustainability mechanisms; local government units

\section{Introduction}

Place branding and urban regeneration are considered drivers of positive change in urban planning. Previous studies have framed place branding as an emerging approach to regenerate cities, stemming from the corporate concept of branding [1-5]. Accordingly, effort must be taken to distinguish place branding from corporate associations with place marketing and place promotion. Unlike corporate products and services, a place is a complex, multidimensional entity that cannot be represented in a single slogan or image $[3,4]$. As the concept of place branding finds its niche within urban planning parlance, work must also be done to meticulously clarify its definition and properties [6].

Currently, the terms place marketing, urban marketing, and place promotion are interchangeable among scholars and studies [7]. Boisen et al. have attempted to distinguish these terms as interrelated means of reaching different goals [5]. Further accordance and the common adoption of such delineations must be pursued in order to establish cohesive frameworks from which to work.

Commonly, place branding has been defined as a highly selective process of differentiating a place through its global relevance, as demonstrated by the ability to leverage a media narrative, economic 
growth, and social capital [5]. Accordingly, studies on place branding span geography, marketing, tourism, and urban studies. Most of the literature written in English has not established a link between place branding and urban regeneration, although attempts have been made by several scholars [8-12].

There are several case studies that have attempted to establish place branding as a tool for urban regeneration; however, most have defined this strategy as the result of the process of branding. As Paddison [13] claims, prior to urban regeneration, the reconstruction of an image of a city is crucial. However, Prilenska [14] has a different view on the process, outlining the idea of place branding as a tool for urban regeneration, basing it on the process made by Kavaratzis [11]. In the study made by Prilenska [14], urban regeneration schemes are heavily reliant on the establishment of flagship projects and development, which she claims to be one of the successful approaches. These successes are attributed to how the presence of the place was changed, and how it generated new gains for the area in terms of economic opportunities.

Moreover, there have been successful cases which define place branding as either a tool for urban regeneration or as a result of the regeneration process in the area. Martinez [9] has compiled several case studies that link urban regeneration with place branding. Among the most notable ones are those in the studies of Paddison [13], which attempted to establish the realm of place branding as urban regeneration. Further, most of the regeneration cases are situated in former industrial cities and aim to revive the area, by introducing new features that will make it attractive to several facets of development $[8,9]$.

Several case studies have investigated cities in developing countries who struggle to maintain and update their spatial conditions. Cities like Guayaquil in Ecuador and Medellin in Colombia are great examples of successful urban regeneration strategies; however, other challenges have made it difficult for them to leverage the regeneration process to create a distinct brand for the city.

Recently, several great examples of cities utilizing place branding as an urban regeneration strategy have emerged $[9,11,13,14]$. Promoting culture and art has been the most commonly used tactic [15] and has led to a rise in public art being introduced as a flagship approach. This has been used as a hybrid place branding strategy, mixing flagship construction through art installations and event branding by introducing art festivals. Postmodernism in urban design and planning has inspired several practitioners and institutions to explore the functions and aesthetics of their public spaces [15].

More broadly, the inception of urban regeneration in the mainstream of spatial development has stemmed from the need to redevelop decaying urban spaces [16]. As such, urban regeneration has a long standing dilemma in the struggle to connect it to a wider scope of sustainability outside the context of the environment alone. This brings us to the idea of a sustainable urban regeneration framework that looks into the lenses of the economy, environment and equity, with the purview of place branding as a strategy. The multi-dimensional approach in the delivery of urban renaissance strategy that fits into the sustainable development paradigm requires four preconditions. These are institutional governance, policy direction, sustainable financing, and, most importantly, proactive stakeholder participation [17-20].

This study attempts to mediate the divergent views of and strategies for place branding, as they relate to urban regeneration. Although many studies have considered place branding and urban regeneration as interrelated processes, there has not been an attempt to establish a conceptual or theoretical link between the two. Consequently, there is a lack of clarity regarding whether place branding is a tool for urban regeneration or urban regeneration is a precondition of place branding. Moreover, few studies have used empirical data or put forth solid theoretical and/or conceptual models to support direct observations [3,14,21-23].

It should be noted that most of the aforementioned studies are highly focused on cities and other areas in developed countries [8-12,21-26], so their results should not necessarily be taken as generalizable, especially with respect to developing countries. 
This study has examined the dialectics of policy and its agents, spanning national government to local government units. The results herein can be considered a starting point in driving policies that will institutionalize place branding as a key strategy for stimulating urban regeneration processes [14].

Specifically, this study highlights the importance of evaluating various place branding strategies based on responses from stakeholders. These responses were treated in the form of dialectics. Considering that urban regeneration is an established place management process, we consider it the center of current research, while place branding, being an emerging strategy stemming from different allied fields, is treated as an antithesis. Using the Hegelian dialectic triad [27] (Figure 1) enabled us to distinguish the two concepts and build a concrete definition of place branding in the context of urban regeneration, that suits the knowledge and perception of the key stakeholders involved in this study. We further hope to introduce contextualized spatial and sectoral strategies, to give this new framework additional value in local development planning. The goal of doing so is to introduce sustainable strategies that are applicable and beneficial to local communities, especially in developing countries.

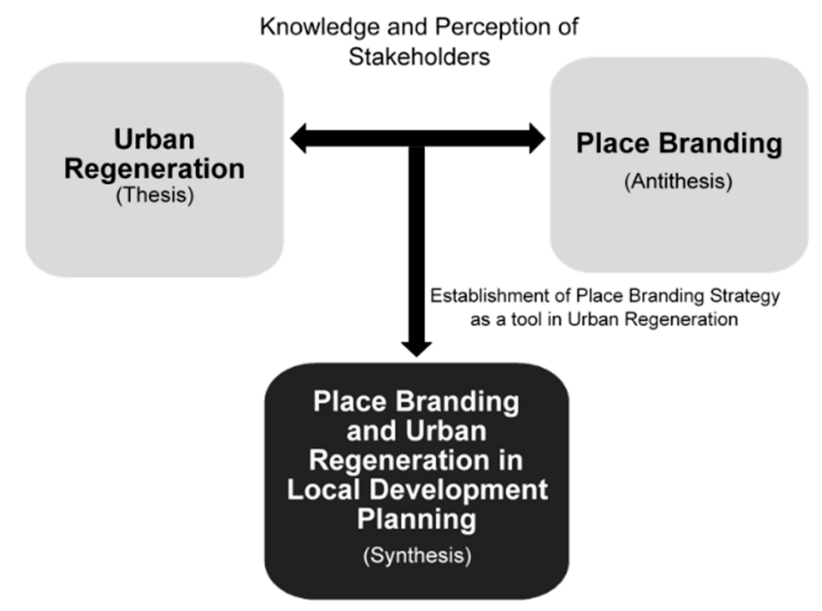

Figure 1. Conceptual framework, as modified from Hegel's dialectic triad.

Materially, we arrived at three common grounds for place branding and urban regeneration based on the perception and knowledge of the stakeholders included in this study. First, place branding and urban regeneration concepts are both perceived to address the process of creating a place's identity, and using it as a leverage for place promotion activities. Second, cultural and heritage preservation are prevalent for both place branding strategies and urban regeneration concepts and third, the establishment or development of a new infrastructure could support the process of place branding and urban regeneration.

In the Philippines, place branding has been focused on destination branding through tourism campaigns. On the other hand, studies on urban regeneration focus on the redevelopment of commercial areas and the emergence of business districts. This study focuses on cities in the Western Visayas Region of the Philippines (Figure 2).

The Western Visayas, or Region 6 (Figure 3), is one of the 18 administrative regions in the Philippines. It is located in the central part of the country, within the Visayas group of islands. The region comprises six provinces, 16 cities, 117 municipalities, and 4050 barangays (villages) and has been one of the fastest-growing regions in the Philippines, in terms of economic growth, over the past two years (2017-2018), averaging 7.4\% in Regional Gross Domestic Product [28]. It is also the fifth largest regional economy outside the National Capital Region. This economic success has been fueled by the increase in production from the service industry, mainly from the Business Process Outsourcing companies, and tourism expenditure receipts [29]. 


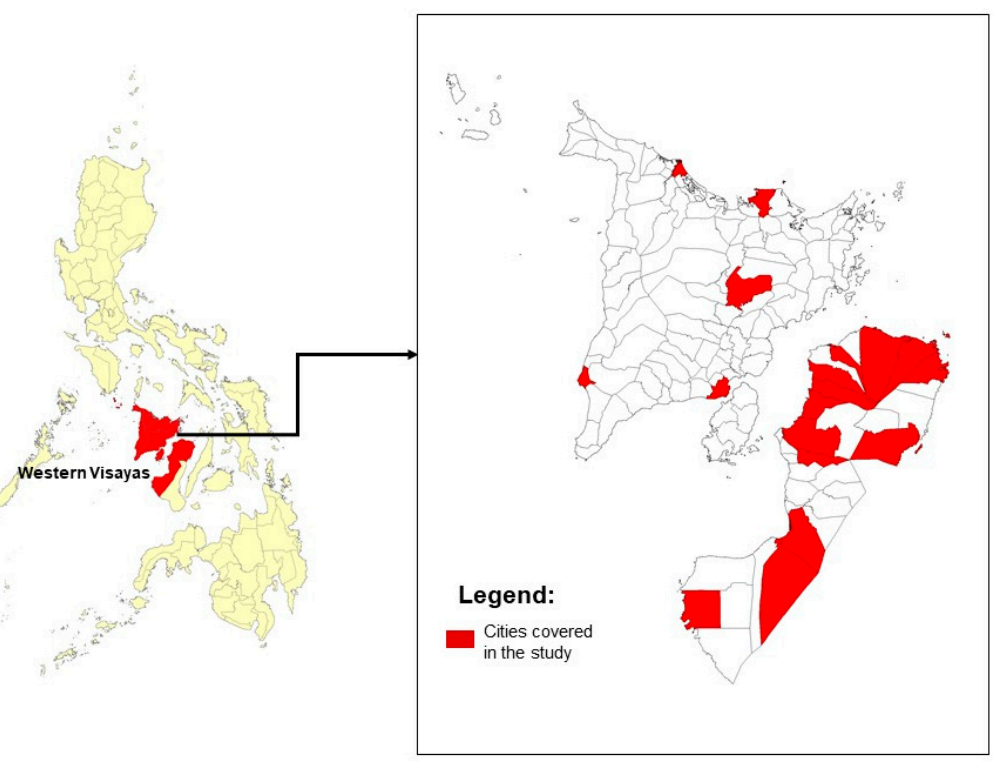

Figure 2. Map of the Western Visayas Region in the Philippines.

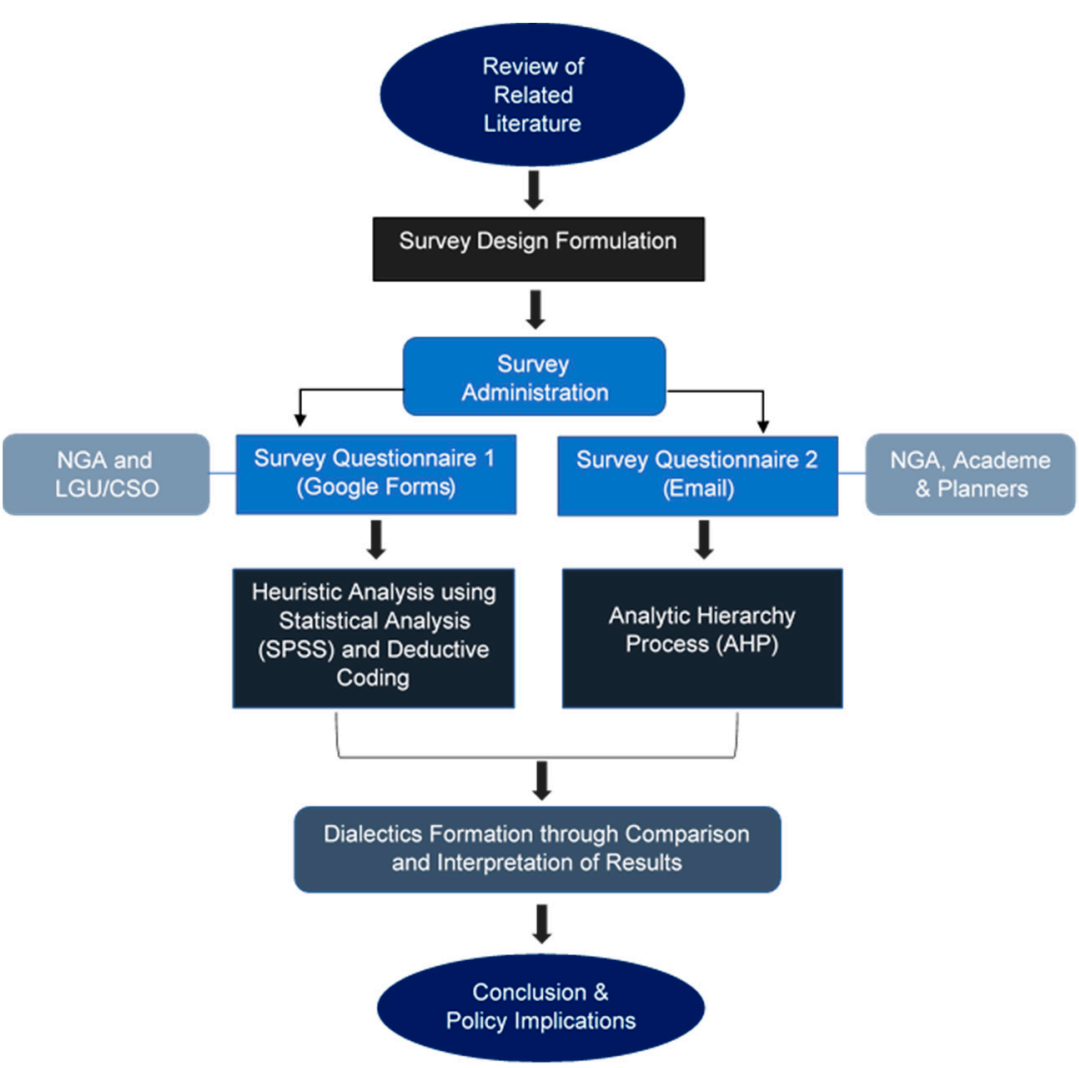

Figure 3. Methodological framework.

The region is considered to be a tourist haven due to its vast historical sites and natural landscapes, including the world-famous Boracay Island and the baroque church of St. Thomas of Villanueva, which is the only UNESCO World Heritage Site outside of Luzon. The Western Visayas are also home to the most cities outside the national capital region. Thirteen of these cities are located in Negros Occidental. Of these, Bacolod City is the de facto capital of the province, while three cities on Panay Island, including Iloilo City, serve as the regional capital.

Several cities in the region were founded during the Spanish and American colonial periods. Thus, they are host to both tangible and intangible historical edifices and traditions. Presently, the 
region's unprecedented urban growth, particularly that of Iloilo City, has made it a key target area to benefit from place branding and urban regeneration.

\section{Materials and Methods}

A mixed-methods approach was used to establish the study foci, and guide the interpretation of qualitative and quantitative data (Figure 3). Two sets of questionnaires were developed to examine how key stakeholders perceived place branding and urban regeneration. In light of the information we received from the reviewed literature, we established objective parameters to evaluate place branding strategies, as categorized by Ashworth and Kavaratzis [30]. We used purposive sampling to select participants based on their involvement and decision-making capacity within different interest groups.

The first set of questionnaires investigated place branding and urban regeneration from the viewpoint of the national government agency (NGA) National Economic and Development Authority, Department of the Interior and Local Government, Housing and Land Use Regulatory Board and Commission on Audits, and local government units (LGUs), including several civil society organizations (CSOs). The first questionnaire consisted of multiple-choice questions, a four-point Likert scale and open-ended questions, and was distributed through a link in a Google Form.

The NGA group was composed of technical and administrative officers, as well as consultants and advisers who were directly involved in the local development planning process, regardless of their experience in place branding or urban regeneration projects. The four target NGA offices had a direct influence on local planning processes, along with the LGUs. From LGUs and CSOs, key officials, including mayors and vice-mayors, technical officers, and consultants/advisers, were selected.

Since purposive sampling was used to select participants, only a few were taken based on the designed criteria. Out of 40 subjects at the NGA offices, 22 responded (55\% response rate), while 40 out of 72 subjects from 13 LGUs responded (55\% response rate). All participants were from cities and capitals within the Western Visayas region.

The results of the survey were analyzed and compared through a heuristic assessment of quantitative data from descriptive statistics, using SPSS software. A mixed-recognition heuristics method and phenomenologic approach were used to interpret data from open-ended questions, which were organized through axial coding. All responses were grouped using common themes and sub-themes to identify responses related to place branding and urban regeneration. The same approach was used to define factors that should be considered as focus areas for cities attempting to adopt place branding strategies.

The second set of questionnaires was designed to introduce place branding strategies for urban regeneration in the Philippines. A total of 30 experts from three different groups were invited to participate in the survey. All respondents were identified based on their involvement with national or local government units in local development planning activities.

Respondents were put into the following groups: representatives of NGAs, members of academic and professional research units, and practitioners from the Philippine Institute of Environmental Planners. Each group had ten sample representatives. Participants from NGAs were identified differently from those who responded to the first questionnaire, in order to avoid conflicting responses and maintain the integrity of our results.

The analytic hierarchy process was used to design the second questionnaire [31]. To develop the criteria and alternatives for the hierarchy model, we reviewed related studies that have suggested several standards and procedures in undertaking place branding. We placed particular emphases on economic, social, cultural, and sustainability dimensions from various templates, such as Anholt's City Branding Elements [5], Saffron City Brand Barometer [32], City Branding Procedures and Toolkit by Yoon [33] and Trueman and Cornelius [34], Rainisto's Place Branding Success Factors [35], and the Place Branding Techniques suggested by Ashworth and Kavaratzis [30].

We set-up six major criteria from the studies we reviewed. Three major place branding strategies were taken from Ashworth and Kavaratzis [30], and three from Zenker and Beckmann [36]. In order to 
evaluate the most common place branding strategies from the literature, strategies were divided into major and sub-category alternatives (Figure 4).

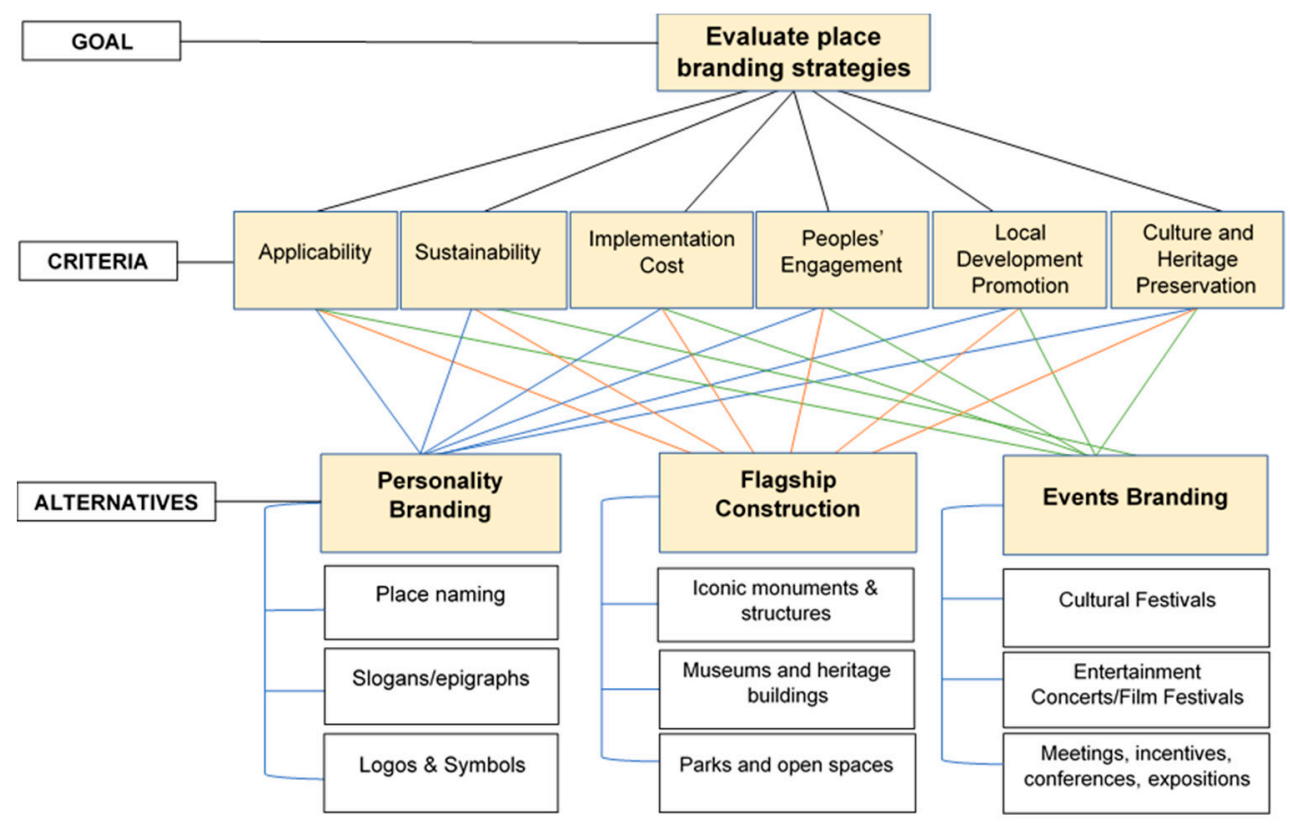

Figure 4. AHP criteria model.

Each alternative was evaluated using a two-way, five-scale, pairwise comparison matrix. Responses were computed using the row geometric mean method (RGMM), as proposed by Golden and Wang [37]. All decisions were computed to ascertain their weight and verified based on consistency, with CR $\leq 0.2$ as the tolerance value [38,39]. After performing these computations, 26 of the 30 responses $(87 \%)$ were used for analysis and later compared to those from the other three groups.

In order to develop general decision criteria, the weighted results were combined using the RGMM, which returned weighted priorities across all three groups. The results from both the heuristic analysis and AHP were deconstructed to form a dialectic argument. This triangulation method helped connect the concepts of place branding and urban regeneration for local development planning.

Finally, a dialectic framework adapted from the Hegelian dialectic triad (Figure 1) was used to conceptually link place branding and urban regeneration [27]. This method, using perception and deductive analysis, allowed the exploration of how major stakeholders' narratives are related to place branding and urban regeneration in the Philippines. Additionally, this was used to generate dialectics formed through the interpretation and comparison of responses. Various studies addressing place branding and urban regeneration were examined to design objective criteria and an evaluation model that would build on the dialectic triad.

\section{Results and Discussion}

The first part of this section deals with responses from LGU and CSO representatives with respect to their experience as direct policy implementers, while those from NGAs were considered with respect to their experience as policy and oversight enforcers. The first topic discussed is the respondents' demographics (Table 1); the second is the association between place branding and urban regeneration, based on the literature as well as respondents' inferences from either experience or practice; the third involves the intersection between place branding and urban regeneration, focusing on sustainability; and the fourth deals with perceived implementation strategies and factors, to be considered by cities before pursuing place branding initiatives. The second discussion point focuses on responses from AHPs. The respondents' demographics are presented in Table 2. We then analyze and compare place branding strategies that are divided into main categories and sub-category alternatives. 
Table 1. Respondents' demographics for Questionnaire 1.

\begin{tabular}{llcccccc}
\hline \multirow{2}{*}{ Categories } & & \multicolumn{2}{c}{ Total } & \multicolumn{2}{c}{ NGA $^{2}$} & \multicolumn{2}{c}{ LGU and CSO $^{\mathbf{3}}$} \\
\cline { 3 - 8 } & & $\mathbf{f}$ & $\mathbf{\%}$ & $\mathbf{f}$ & $\mathbf{\%}$ & $\mathbf{f}$ & $\mathbf{\%}$ \\
\hline \multirow{3}{*}{ Gender } & Male & 31 & 50 & 8 & 36 & 23 & 58 \\
& Female & 31 & 50 & 14 & 64 & 17 & 43 \\
& Total & 62 & 100 & 22 & 100 & 40 & 100 \\
\hline \multirow{3}{*}{ Work Experience } & 0-5 years & 8 & 13 & 1 & 5 & 7 & 17.5 \\
& 6-10 years & 18 & 29 & 10 & 45 & 8 & 20 \\
& 11-15 years & 8 & 13 & 4 & 18 & 4 & 10 \\
& 16-20 years & 7 & 11 & 0 & 0 & 7 & 17.5 \\
Involvement in Place & Y20 years & 21 & 34 & 7 & 32 & 14 & 35 \\
Branding/Urban & Total & 62 & 100 & 22 & 100 & 40 & 100 \\
Regeneration Projects & No & 20 & 40 & 6 & 27 & 16 & 40 \\
& Total & 42 & 84 & 16 & 73 & 24 & 60 \\
\hline
\end{tabular}

Note: ${ }^{2}$ National government agency; ${ }^{3}$ local government unit, and civil society organization. Source: Heuristic analysis questionnaires collected between July and August, 2019.

Table 2. Respondents' demographics for Questionnaire 2.

\begin{tabular}{cccccccccc}
\hline \multirow{2}{*}{ Categories } & \multicolumn{2}{c}{ Total } & \multicolumn{3}{c}{ NGA Officers } & \multicolumn{3}{c}{ Researchers/AcademiPsanners } \\
\cline { 3 - 9 } & & $\mathbf{f}$ & $\mathbf{\%}$ & $\mathbf{f}$ & $\mathbf{\%}$ & $\mathbf{f}$ & $\mathbf{\%}$ & $\mathbf{f}$ & $\%$ \\
\hline \multirow{3}{*}{ Gender } & Male & 12 & 40 & 5 & 50 & 5 & 50 & 2 & 20 \\
& Female & 18 & 60 & 5 & 50 & 5 & 50 & 8 & 80 \\
& Total & 30 & 100 & 10 & 100 & 10 & 100 & 10 & 100 \\
\hline \multirow{3}{*}{ Work } & $3-9$ years & 12 & 40 & 4 & 40 & 4 & 40 & 4 & 40 \\
Experience & $10-19$ years & 11 & 37 & 3 & 30 & 4 & 40 & 4 & 40 \\
& $\geq 20$ years & 7 & 23 & 3 & 30 & 2 & 20 & 2 & 20 \\
& Total & 30 & 100 & 10 & 100 & 10 & 100 & 10 & 100 \\
\hline
\end{tabular}

Source: AHP Questionnaire collected between July and August, 2019.

In terms of demographics, $34 \%$ of the heuristics respondents had over 20 years of work experience (Table 1); however, only $20 \%$ had been involved in place branding and/or urban regeneration projects. This makes sense, given that most place branding and urban regeneration projects in the study area were carried out by the private sector, with little involvement from public institutions like LGUs and NGAs. We define involvement as contributing to the conceptualization, planning, implementation, monitoring, and evaluation of such projects. Conversely, 40\% of AHP respondents (Table 2) were relatively inexperienced, ranging from 3-9 years of relevant work. In the Philippines, the most active planners and designers are in this age bracket.

\subsection{Heuristic Analysis}

\subsubsection{Association of Place Branding with Urban Regeneration}

To define place branding and urban regeneration, with respect to the dialectics derived from the two sets of stakeholders (LGUs and NGAs), we compared the between-group means regarding the perception of key terms, as referenced in key case studies. A similar approach was used to evaluate open-ended questions which asked respondents to define concepts based on their inferences and experiences (Table 3). Specifically, each group was asked to identify the top three items from a list of choices that they perceived as being associated with place branding and urban regeneration. These were the terms generated from the studies that deal separately with place branding and urban regeneration as different concepts, although both tend towards promoting culture and the arts, and 
heritage preservation. This process allowed us to distinctively build the two concepts before dealing with the commonalities discussed in the succeeding parts of this paper.

Table 3. Measurement and scoring of variables.

\begin{tabular}{|c|c|c|}
\hline Theme/Questions & Variables & Measurement and Scoring \\
\hline Place Branding & $\begin{array}{l}\text { Unique Architectural Structures } \\
\text { Culture and Arts } \\
\text { Festivals and Other Events } \\
\text { Slogans and Logos } \\
\text { Tourism }\end{array}$ & $\begin{array}{c}\text { Multiple Choice (Top 3) } \\
\text { Very High Association }=1 \text {, High } \\
\text { Association }=2 \text {, Slightly High } \\
\text { Association }=3\end{array}$ \\
\hline What is your idea of a place brand? & & Open-ended question \\
\hline Urban Regeneration & $\begin{array}{c}\text { Culture and Heritage Preservation } \\
\text { Revitalization of Commercial Districts } \\
\text { New Housing and Mixed Used Development } \\
\text { Redevelopment of Former Industrial Sites } \\
\text { New Use of Urban Spaces }\end{array}$ & $\begin{array}{c}\text { Multiple Choice (Top } 3 \text { ) } \\
\text { Very High Association = } 1 \text {, High } \\
\text { Association }=2 \text {, Slightly High } \\
\text { Association }=3\end{array}$ \\
\hline $\begin{array}{l}\text { What is your idea of urban } \\
\text { regeneration? }\end{array}$ & & Open-ended question \\
\hline
\end{tabular}

Source: Questionnaire designed for heuristic analysis.

The results revealed that both groups identified slogans and logos as the most highly associated items, followed by unique architectural structures (Table 4). Conversely, LGU representatives associated place branding with festivals and other events, while those from the NGA correlated culture and arts with this topic. This difference can be explained by the fact that local governments are the policy implementers on the ground in the Philippines, which explains their focus on festivals as signifiers of a place branding strategy. Alternatively, the national government serves as a policy-making and oversight entity; therefore, representatives focused on abstract concepts such as culture and arts.

Table 4. Association of place branding concepts from key case studies.

\begin{tabular}{ccccc}
\hline & \multicolumn{2}{c}{ NGA } & \multicolumn{2}{c}{ LGU } \\
\hline & Mean & SD & Mean & SD \\
\hline Unique Architectural Structures & 1.14 & 1.17 & 1.03 & 1.17 \\
Culture and Arts & 1.27 & 1.24 & 1.40 & 1.13 \\
Festivals and Other Events & 1.18 & 1.14 & 1.78 & 1.00 \\
Slogans and Logos & 0.68 & 0.99 & 0.88 & 1.22 \\
Tourism & 1.50 & 1.22 & 1.68 & 1.31 \\
\hline
\end{tabular}

Source: Heuristic analysis [Q: 1. Which concepts below do you associate with place branding? (Choose 3)].

Slogans, logos, and unique architectural structures were most frequently cited in case studies pertaining to place branding initiatives, because of their visual impact and recognizability $[8,9,13,24]$. In the Philippines, this strategy is most widely associated with tourism promotion, wherein most major cities align themselves with national and regional branding strategies from the Department of Tourism. As such, strategies employed by the tourism department can be inferred as an influence on the respondents' recognition of slogans and logos as branding strategies.

Responses from both groups were grouped into two major themes, with distinct sub-themes (Table 5). Products and Services and Positive Image Building were the primary sub-themes identified by LGU respondents, under the major theme of Place Promotion. On the other hand, the NGA respondents recognized Marketing and Packaging and Image Projection and Association as sub-themes. As Boisen et al. [5] posit, place branding brings into focus the need to build a positive image for the city. One respondent has noted that a place's brand is needed, considering that, "such idea translates 
the major motivation of [in] establishing a brand for the city, in order to make it visible in the external market, [and] to gain a much needed competitive advantage, brought by the positive image projection."

Table 5. Association of place branding concepts from inference and experience.

\begin{tabular}{cll}
\hline & \multicolumn{1}{c}{ Major Theme } & \multicolumn{1}{c}{ Sub-Themes } \\
\hline \multirow{2}{*}{ LGU } & Place Promotion & $\begin{array}{l}\text {-Products and services } \\
\text {-Positive image-building }\end{array}$ \\
\cline { 2 - 3 } NGA & Place Identity & $\begin{array}{l}\text {-Distinct city identity and character } \\
\text {-Trademarks, labels, and symbols }\end{array}$ \\
\cline { 2 - 3 } & Place Promotion & $\begin{array}{l}\text {-Marketing and packaging } \\
\text {-Image projection and association }\end{array}$ \\
\cline { 2 - 3 } & Place Identity & $\begin{array}{l}\text {-Livability } \\
\text {-Uniqueness of place }\end{array}$ \\
\hline
\end{tabular}

Source: heuristic analysis (Q: What is your idea of a place brand?).

The second major theme identified by both groups was Place Identity. Although both groups referred to Uniqueness of Place and Identity in the form of trademarks, labels, and symbols as particularly salient, the NGA representatives placed greater emphasis on Livability. One of the respondents defined this concept as "... a sense that the place can cater [to] the needs of the present while ensuring that the future generations' aspirations and desires will be catered to as well." Moreover, one LGU participant posited that, in establishing place identity, the "whole of a place-experience" should be a city's focus when creating its own brand. The participant further elaborated that: "Experiences can be more memorable and meaningful if people come to a place where most aspects of their presence have been affected or has created more impact to them. People will talk more about a place they have "experienced" more-everything they have felt, smelled, tasted or heard-and a city/town should try its best to make these entire experience positive. In planning, we should always remember that the "sum of the parts is greater than the whole". If this happens, people will continually/constantly go back to a place for more wonderful experiences.

In the case of urban regeneration, the only commonality between both groups was their view of the redevelopment of former industrial sites. LGU representatives identified New Housing and Mixed-used Development, as well as New Use of Urban Spaces, as drivers of urban regeneration, while those from NGAs emphasized Culture and Heritage Preservation, as well as Revitalization of Commercial Districts (Table 6). Expounding on the Culture and Heritage Preservation view of the NGA respondents, one of them has noted the need for " ... preservation and adaptive re-use of heritage sites/structures", as an element of urban regeneration. On the other hand, an LGU respondent expressed the perception of regenerating cities as its "... revive[ing] its urban spaces by developing its features, [and] improvement of [its] spaces". It is important to note that the LGU representatives were primarily from cities experiencing rapid urbanization.

Table 6. Association of urban regeneration concepts from the literature.

\begin{tabular}{ccccc}
\hline & \multicolumn{2}{c}{ NGA } & \multicolumn{2}{c}{ LGU } \\
\hline & Mean & SD & Mean & SD \\
\hline Culture and Heritage Preservation & 0.773 & 0.752 & 1.525 & 1.219 \\
Revitalization of Commercial Districts & 1.227 & 1.193 & 1.575 & 1.010 \\
New Housing and Mixed Used Development & 1.227 & 1.307 & 0.900 & 1.105 \\
Redevelopment of Former Industrial Sites & 0.909 & 1.192 & 0.600 & 1.057 \\
\hline
\end{tabular}

Source: Heuristic analysis. [Q: What is your idea of urban regeneration? (Choose 3)]. 
In the Philippines, mixed use policies facilitate high-density development and low land area requirements. Moreover, the Philippine national government promotes the preservation of culture and heritage in all urban planning doctrines and revitalization projects. Doing so empowers local governments to generate income through tourism.

There was good accordance between stakeholders' inferences regarding place branding and urban regeneration and those mentioned in key studies (Table 7). Both groups linked urban regeneration to place promotion through the staging of annual cultural festivals. Throughout the year, cities in the Western Visayas hold festivals as part of their tourism campaigns.

Table 7. Urban regeneration concepts based on inference and experience.

\begin{tabular}{|c|c|c|}
\hline & Major Theme & Sub-Themes \\
\hline \multirow{3}{*}{ LGU } & Place Promotion & $\begin{array}{l}\text {-Promotion of local festivals and destinations } \\
\text {-Creating a city identity }\end{array}$ \\
\hline & $\begin{array}{l}\text { Historical and Cultural } \\
\text { Preservation }\end{array}$ & -Reviving historical places \\
\hline & Revitalization of Urban Spaces & $\begin{array}{l}\text {-Developing new infrastructure } \\
\text {-Renewing urban neighborhoods } \\
\text {-Reviving commercial districts } \\
\text {-Recovering parks and open spaces }\end{array}$ \\
\hline \multirow{3}{*}{ NGA } & Place Promotion & -Staging annual festivals \\
\hline & $\begin{array}{l}\text { Historical and Cultural } \\
\text { Preservation }\end{array}$ & $\begin{array}{l}\text {-Establishing heritage corridors } \\
\text {-Re-using heritage structures }\end{array}$ \\
\hline & Revitalization of Urban Spaces & $\begin{array}{l}\text {-Renewing old downtown districts } \\
\text {-Constructing new and better facilities } \\
\text {-Establishing new uses for existing urban spaces }\end{array}$ \\
\hline
\end{tabular}

Source: Heuristic analysis. (Q: Which examples you think exemplify how branding a city can help revive its urban spaces?).

On the other hand, historical and cultural preservation were among the major themes through which both groups linked urban regeneration with the preservation of historical places. For instance, the national government has tended to create heritage corridors. Further, developing new infrastructure was one of the common sub-themes for representatives from both the local and national governments. Representatives from local governments showed an intuitive inclination toward the renewal of urban neighborhoods, while those from the national government preferred to associate urban regeneration with the renewal of old downtown districts.

The association of concepts from the literature and those inferred from interviews enabled a common perceptual framework. In particular, place branding was highly associated with slogans and logos and, more broadly, visual strategies to promote local culture and arts. Moreover, the introduction of unique architectural structures was perceived as adding a physical identity to a given place $[14,36]$.

Kalandides [40] asserted that the link between place branding and identity is crucial to ensure that the 'right image' is projected by a community. In this vein, urban regeneration signifies a pervasive manifestation of urban renewal, particularly of old commercial or industrial districts. This necessitates consideration of cultural and historical significance during the revitalization process. Notably, Lucarelli and Brorstrom [3] espoused this ethos when they defined place branding as being inclusive of strategies to regenerate cities.

3.1.2. Association, by Level of Importance, of Place Branding Strategies and Their Intersection with Urban Regeneration

Ashworth and Kavaratzis [2] grouped place branding strategies into three types: personality branding, flagship construction, and event branding. Using these three designations, respondents from 
each group were asked to define the levels of importance of particular statements about the different attributes of each place branding strategy (Figure 5).
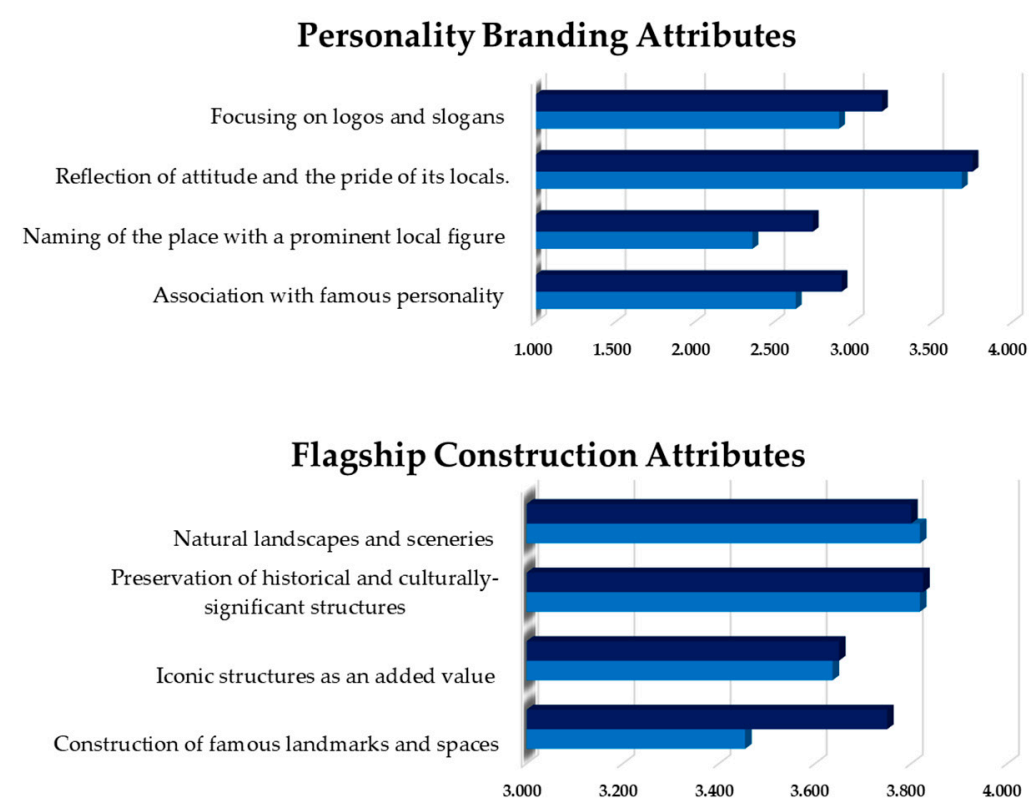

\section{Events Branding Attributes}

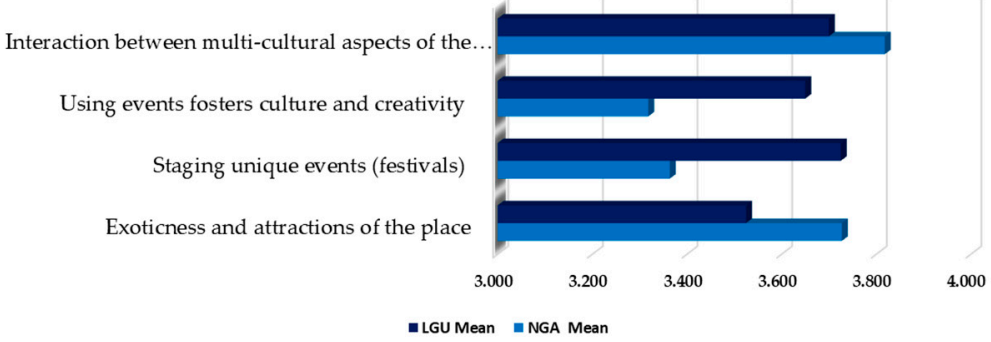

Figure 5. Perceptions of place branding strategies.

The same sets of participants from the LGUs and NGA were asked to rate the levels of importance of several themes that were omitted from the questionnaires. These themes were represented by associative statements aiming to elucidate stakeholders' perception of common strategies used for place branding. Likewise, statements that explicitly and implicitly linked place branding with urban regeneration were provided to establish the relevance of such an intersection based on the level of importance indicated by the stakeholders.

Both groups associated personality branding with peoples' attitudes toward and pride for a place. Similarly, Ashworth and Kavaratzis [2] noted that personality branding focuses on the inscription of individuals' unique characteristics to a place to which they belong. Conversely, both groups rated the flagship construction strategy as highly associated with the preservation of historical and culturally significant structures such as monuments, churches, and houses. Such an association can be explained by the existence of various historical and cultural structures in the area of study. Many cities throughout the world have utilized the same strategy $[9,35]$.

In the case of events branding, both groups differed with respect to the statements they regarded as highly associated with this strategy. Representatives from the national government placed the highest associative importance on multi-cultural aspects of various cities. This was more abstract than placemaking associations made by representatives from LGUs, who preferred staging unique events such as annual festivals. Unsurprisingly, both groups ascribed the highest level of importance to 
flagship construction. Its prominence can be attributed to its architectural notability and noticeability. As such, this strategy has become an easy way to get local place branding policies to be adopted [2]. In addition, we examined how the NGA and LGU groups identified and associated statements regarding place branding and urban regeneration, as well as preconditions for successful strategy implementation. We also prompted them to think about how sustainability mechanisms relate to place branding strategies (Table 8). Both groups ascribed high importance to peoples' participation in the process of place branding and urban regeneration. Several case studies corroborate this importance $[4,10,35]$.

Table 8. Associations between the intersection, precondition, and sustainability mechanisms of place branding and urban regeneration.

\begin{tabular}{|c|c|c|c|c|}
\hline \multirow{2}{*}{$\begin{array}{c}\text { Intersection of Place Branding and Urban } \\
\text { Regeneration }\end{array}$} & \multicolumn{2}{|c|}{ NGA } & \multicolumn{2}{|c|}{ LGU } \\
\hline & Mean & SD & Mean & SD \\
\hline Whole of place experience & 3.818 & 0.395 & 3.750 & 0.588 \\
\hline Strategy to regenerate decaying urban areas & 3.545 & 0.596 & 3.525 & 0.599 \\
\hline Building sense of place ownership & 3.818 & 0.501 & 3.575 & 0.594 \\
\hline People-centered & 3.864 & 0.351 & 3.800 & 0.405 \\
\hline Location as a significant factor & 3.409 & 0.666 & 3.675 & 0.572 \\
\hline Reflection of regeneration and fresh ideas & 3.773 & 0.429 & 3.675 & 0.474 \\
\hline \multirow{2}{*}{$\begin{array}{c}\text { Preconditions for Successful Place Branding and } \\
\text { Urban Regeneration }\end{array}$} & \multicolumn{2}{|c|}{ NGA } & \multicolumn{2}{|c|}{ LGU } \\
\hline & Mean & SD & Mean & SD \\
\hline $\begin{array}{c}\text { Understanding socio-cultural, political and economic } \\
\text { status }\end{array}$ & 3.955 & 0.213 & 3.850 & 0.362 \\
\hline Leadership and public private partnerships & 3.864 & 0.351 & 3.850 & 0.362 \\
\hline Governance and business climate & 3.818 & 0.395 & 3.875 & 0.335 \\
\hline Presence of strategic vision for the place & 3.818 & 0.395 & 3.750 & 0.494 \\
\hline Examined city assets & 3.591 & 0.908 & 3.800 & 0.405 \\
\hline Showcasing of a place's strength and distinction & 3.682 & 0.568 & 3.875 & 0.335 \\
\hline \multirow{2}{*}{ Sustainability Mechanisms } & \multicolumn{2}{|c|}{ NGA } & \multicolumn{2}{|c|}{ LGU } \\
\hline & Mean & SD & Mean & SD \\
\hline Consistency with the vertical brands & 3.364 & 0.848 & 3.425 & 0.747 \\
\hline Involvement of public relation firms in the city & 3.045 & 0.844 & 3.150 & 0.864 \\
\hline People's participation & 3.955 & 0.213 & 3.775 & 0.480 \\
\hline Reflection of social purpose & 3.818 & 0.395 & 3.675 & 0.526 \\
\hline Creation of a message house & 3.636 & 0.492 & 3.500 & 0.599 \\
\hline Communication as a means of creating a global appeal & 3.955 & 0.213 & 3.900 & 0.304 \\
\hline
\end{tabular}

Source: Heuristic analysis (associative statements in a four-point Likert scale for intersection, preconditions and sustainability mechanisms of place branding).

Both place branding and urban regeneration were considered highly dependent on their having people to mobilize them. While place branding appeared to be the least important contributing factor to the success of urban regeneration, it was still perceived to be significantly intertwined with urban regeneration among stakeholders, despite the fact that Martinez [9] and Prilenska [14] have already established a link between place branding and urban regeneration with respect to local economic development, given that both attract industries and highly-skilled people.

The two groups were also asked to define, by level of importance, the pre-conditions that would ensure success in place branding and urban regeneration (Table 8). Respondents from the national government suggested that it is critical to understand a community's socio-cultural, political, and economic status prior to pursuing place branding or urban regeneration strategies. This is necessary to guarantee that the strategies address the needs of a community and their implementation is within the bounds of its resource capability. Likewise, such place branding and urban regeneration strategies should fit with a place's cultural identity [41,42]. 
Rainisto [35] also asserted that it is critical for a city, town, or community to understand its socio-cultural and socio-economic conditions in order to brand its identity. In this vein, local government respondents noted the importance of establishing a place's strong governance and business climate. Doing so differentiates one place from another and can be used to seek support from the government and business investors [35].

Both groups saw communication and civic participation as pillars of sustainable place branding and urban regeneration. The sustainability of these strategies should be reflected through a long-term value created by the place identity. Often, these pillars are abandoned when the systems, structures, and policies within a city change.

\subsection{Establishing Objective Criteria in Selecting Place Branding Strategies through the AHP}

This part of the study uses the AHP to determine which strategies could be implemented in the Philippines by establishing empirical evaluation criteria for place branding strategies. Based on the judgment of three expert groups, three major alternatives and sub-alternatives were evaluated using the six criteria defined in the decision hierarchy model (See Figure 3). The results from each group enabled us to delineate experts' priorities with respect to place branding strategies (Table 9).

In this case, experts from the NGA put more weight on event branding, except with respect to sustainability. Here, flagship construction was deemed more than three times as important as event branding. Such a focus on event branding can be inferred from the role of the national government as a policy enabler, rather than an implementer.

On the other hand, experts from academia and practitioners unanimously favored flagship construction over the other two alternatives. Academics put five times more weight on event branding. This could be due to the pervasiveness and perpetuity of cultural festivals present in various LGUs. Nevertheless, flagship construction was the top priority for academic experts and practitioners. This result was likely influenced by case studies and examples from previous sections of this paper.

Additionally, these groups were inclined to grand and visionary approaches compared to their counterparts in the national government, as the latter's main considerations were budgetary requirements and policy regulations. This implies that, in the absence of objective criteria, implementation of place branding strategies will differ depending on which group takes the lead. In the local development planning parlance, these uncoordinated approaches will result in a waste of resources and neglect of the actual needs of a city or community.

Experts from the academe and planners association were more idealistic and frugal in terms of planning and execution. They emphasized creating a lasting impression via architectural structures. Citizens' engagement and sustainability were identified as having the highest value for those in academia. Flagship construction was identified as the most important factor to consider when considering a place branding strategy. This group believed that such a strategy could promote stakeholders' participation in the execution of place branding strategy through consultations, meetings, and dialogues. Various authors, such as Kavaratzis and Ashworth [2], Martinez [9] and Prilenska [14], did not share the same viewpoint. Kavaratzis and Ashworth [2] saw this strategy as a failure to translate impact into other urban benefits in the built environment. The reasons behind this could be attributed to several outcomes of similar strategies which end up as non-functional structures in the city, thereby reducing them to 'white elephant' projects. These structures failed to gain traction in attracting opportunities to support local economic development, as most of these are highly specialized in terms of feature and uses.

In the case of planners, culture and heritage preservation were seen as being the core of promoting flagship construction. In the past decade, most projects in the region have involved heritage conservation, which has included the preservation of old districts, houses, buildings, and other infrastructure related to the city's historical and cultural identities. Moreover, the construction of museums and open public spaces could have contributed to the preference for this strategy. 
Table 9. Experts' priorities regarding place branding strategies.

\begin{tabular}{|c|c|c|c|c|c|c|c|c|c|}
\hline \multirow{2}{*}{$\begin{array}{c}\text { Criteria/ } \\
\text { Alternatives }\end{array}$} & \multicolumn{3}{|c|}{ NGA } & \multicolumn{3}{|c|}{ Academe/Researchers } & \multicolumn{3}{|c|}{ Planners } \\
\hline & $\begin{array}{c}\text { Personality } \\
\text { Branding }\end{array}$ & $\begin{array}{c}\text { Flagship } \\
\text { Construction }\end{array}$ & Events Branding & $\begin{array}{c}\text { Personality } \\
\text { Branding }\end{array}$ & $\begin{array}{c}\text { Flagship } \\
\text { Construction }\end{array}$ & Events Branding & $\begin{array}{c}\text { Personality } \\
\text { Branding }\end{array}$ & $\begin{array}{c}\text { Flagship } \\
\text { Construction }\end{array}$ & Events Branding \\
\hline Applicability & 0.226 & 0.316 & 0.358 & 0.123 & 0.371 & 0.506 & 0.265 & 0.508 & 0.227 \\
\hline Sustainability & 0.267 & 0.345 & 0.287 & 0.146 & 0.562 & 0.292 & 0.235 & 0.413 & 0.352 \\
\hline Implementation Cost & 0.261 & 0.297 & 0.342 & 0.163 & 0.550 & 0.287 & 0.279 & 0.378 & 0.343 \\
\hline Peoples' Engagement & 0.255 & 0.254 & 0.391 & 0.179 & 0.583 & 0.238 & 0.246 & 0.506 & 0.248 \\
\hline Local Development Promotion & 0.272 & 0.259 & 0.368 & 0.166 & 0.547 & 0.288 & 0.256 & 0.535 & 0.209 \\
\hline Culture and Heritage Preservation & 0.206 & 0.267 & 0.427 & 0.315 & 0.383 & 0.303 & 0.173 & 0.581 & 0.247 \\
\hline Total Weight & 1.487 & 1.739 & 2.174 & 1.092 & 2.996 & 1.913 & 1.453 & 2.921 & 1.626 \\
\hline Mean & 0.248 & 0.290 & 0.362 & 0.182 & 0.499 & 0.319 & 0.242 & 0.487 & 0.271 \\
\hline
\end{tabular}


Looking at the overall results (Table 10), flagship construction was considered more than five times more important than other strategies for place branding and urban regeneration, with the most weight coming from researchers and planners. Alternatively, the NGA group leaned toward events and personality branding. In order to meaningfully prioritize strategies, we constructed sub-alternatives consisting of common approaches underlying each of the major alternatives (Figure 6).

Table 10. Overall results of experts' priorities.

\begin{tabular}{llccc}
\hline \multicolumn{1}{c}{ Alternatives } & Experts' Group & Local Weight & Composite Weight & Order of Priority \\
\hline \multirow{2}{*}{ Personality } & NGA & 0.248 & 0.149 & 3 \\
Branding & Researchers & 0.182 & & \\
& Planners & 0.242 & & \\
\hline \multirow{2}{*}{ Flagship } & NGA & 0.290 & 0.527 & 1 \\
Construction & Researchers & 0.499 & & 2 \\
& Planners & 0.487 & 0.300 & 2 \\
\hline \multirow{2}{*}{ Events Branding } & NGA & 0.362 & & \\
& Researchers & 0.319 & & \\
\hline
\end{tabular}

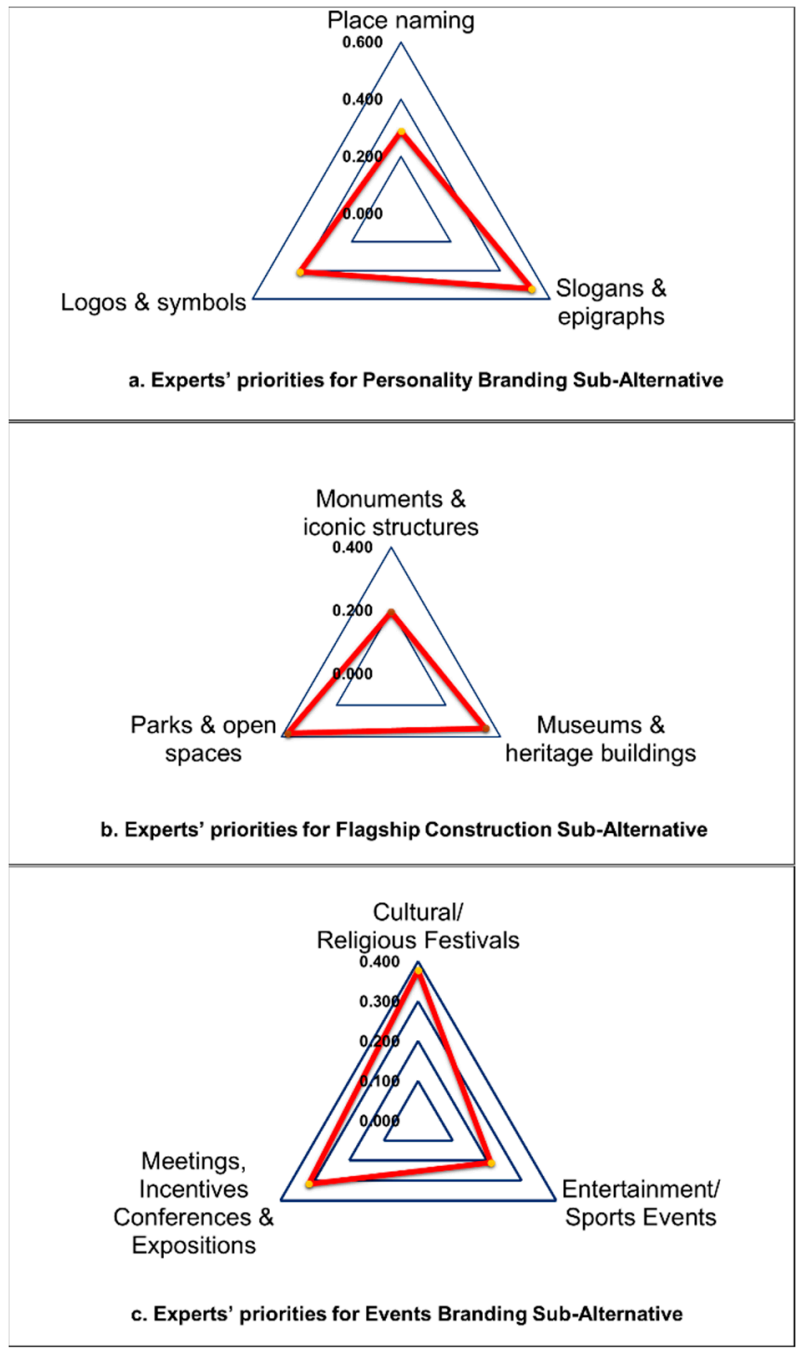

Figure 6. Experts' priorities for specific sub-alternatives. 
For personality branding, experts chose slogans and epigraphs as a preferred low-cost place branding alternative. Govers and Go [43], mentioned that such an approach could effectively materialize a place's image because it can engender easy recall in citizens and serve as a symbolic way of telling local stories.

Parks and open spaces were preferred by experts as sub-alternatives under flagship construction. This trend has been common in place management, wherein ample space is designated for parks and open spaces to allow for public interaction. These parks and open spaces become landmarks and points of reference that exemplify the physical and territorial nature of place branding.

Lastly, in the context of event branding, staging cultural and religious festivals carried the most weight among sub-alternatives. This was likely influenced by a growing trend toward promotional efforts focused on the cultural aspects of community-wide events [44-47]. These strategies have become integrated into the local planning practices of most major cities in the region [2]. Staging these festivals was already common practice in the cities covered in this study. Almost every city had its own unique cultural and religious festivities that helped formulate a distinct brand. An example of this is the yearly Dinagyang Festival of Iloilo City, which is one of the most popular festivals in the country.

\subsection{Building the Dialectic Framework for Place Branding and Urban Regeneration}

The results of this study suggest that place branding is an emerging concept that is related to urban regeneration. By exploring associations between related terms from various key studies, we have found that place branding struggles to distinguish itself from concepts like place marketing and place promotion, given that several researchers and scholars maintain different meanings for these terms [3]. Place promotion and marketing focus heavily on selling a place as a product or a service, which is common when a city attempts to expand destination or tourism marketing.

This study offers a means to define concepts that were highly relatable to the target stakeholders. The dialectics allowed this paper to understand the context of place branding and urban regeneration, and the areas of convergence with the field of local development planning. The notable difference in the perception of both the LGUs and the NGAs regarding their association of place branding and urban regeneration has significantly suggested a sporadic view of these terms. However, we noted several points of interest that link the two concepts; therefore, this study can form a definition where place branding can operate as a strategy in the urban regeneration process. In this definition, flagship construction remains a highly associated place branding strategy, while preservation of cultural assets is strongly reflective of urban regeneration. As such, this study has an opportunity to build a definition for place branding within this framework. It could be inferred from these results that place branding can serve as a basis for urban regeneration strategies that focus on creating a place identity by introducing unique architectural or structural edifices that make the urban built environment stand out from the rest, while preserving its culture and heritage.

Though terms such as place promotion and marketing continue to be used interchangeably, the results of this study have framed place branding as an umbrella concept that can be linked to urban regeneration due to its emphasis on leveraging cultural and heritage preservation to promote a place.

\section{Conclusions and Policy Implications}

The dialectics put forth in this study allowed us to explore the definitions of place branding and urban regeneration in the context of local development planning through key actors from both the national and local governments. Given that the two concepts are still differentially defined across a wide spectrum of studies, there is a need to refine the concepts through a policy document that considers the material and immaterial aspects of urban governance, urban policy, and urban development [2,4,47].

In exploring the dialectics of the key actors involved, this study has established a convincing argument that place branding and urban regeneration, although viewed differently in some aspects, have several intersecting points. These intersecting points provide, from the dialectics, a unity of association for both concepts, despite the fact that urban regeneration is an established process in 
spatial management, while place branding is still finding its niche in urban governance parlance. However, the fundamental aspect of dialectics, to present negation between the two concepts, could not be attributed to the result, as both process are considerably intertwined with each other, wherein both could provide impactful opportunities in place development and management.

Despite the divergent interpretations of these concepts among participants in this study, we were able to establish a link between the two. We conclude that both terms focus on promoting a place through various initiatives, primarily those dealing with historical and cultural preservation. As such, place promotion has provide comprehensive value for the two approaches.

Considering that building a place's identity is essential to place branding [34], an ancillary aim of this study is to incite further inclusion of dialectics as a process for identifying appropriate place branding strategies, regardless of whether or not place branding contributes to the urban regeneration process, or vice versa. Such processes will strengthen the value of promoting a more people-centric approach. This is important in creating a sense of ownership among the people who will be core to the sustainability of place branding strategies.

Notably, flagship construction as a place branding strategy has been widely acknowledged as the most valuable among the alternatives presented. However, such an approach requires further assessment using the criteria established in the AHP model provided by this study. This means that disagreement between NGA representatives, who placed more emphasis on event branding compared to the researchers and academic groups, and LGUs, should be addressed prior to the application of this strategy.

This disconnect among experts can be viewed as an opportunity for collaboration. As policy overseers, NGAs - particularly the National Economic and Development Authority, Department of the Interior and Local Government, and the Housing and Land Use Regulatory Board-could leverage experts from academia and planners to come up with policies to guide LGUs in their efforts to promote places through place branding. Similarly, establishing urban regeneration guidelines spearheaded by the newly created Department of Human Settlements and Urban Development could create harmony among the ongoing redevelopment efforts of various cities [48].

Further, collaboration with key stakeholders should facilitate the integration of capacity development interventions for planners in all sectors to elicit familiarity regarding the key concepts and elements of place branding and urban regeneration. These kinds of partnerships in developing countries like the Philippines could ensure that place branding does not focus on tourism, but rather works toward improving local economies by empowering them to highlight their unique identities in addressing their needs and goals.

This study defines place branding as a strategy that can be employed in the urban regeneration process, which aims to establish a place's identity, focusing on culture and heritage preservation, while paving the way for the development of new infrastructure in the place. This definition can be applied in various contexts and in mediating the opinions of key stakeholders. In utilizing dialectics as a method of analysis, this study can provide a robust framework for evaluating stakeholders' opinions in order to put forth definitions and thematic mapping of concepts.

As an initial attempt to propose a definition of place branding in the urban planning context, we recommend that practitioners and policy makers consider the dynamics of the place, as it continuously evolves with the rise of new technology, and several phenomena like migration and urbanization. In establishing a place identity, they have to look into aspects of changes that could affect the strategy for creating a distinct brand for the place, which could be examined by future researches in the field.

The meta-analysis and inference approach are used this study to document the perception of key concepts based on their experiential value as well as quantitative metrics. What makes this study different from others that deal with the same subject matter is its consideration of key policy actors, as opposed to consumers and visitors. Despite its limitations in terms of scope and coverage, this study offers an initial theoretical model for understanding the concepts of place branding and urban 
regeneration, while also introducing an objective method of evaluating strategies toward these ends for practical use.

Place branding remains a growing concept, so more studies need to be conducted to widen its academic and practical discourses. A further evaluation of groups could be include those who have been involved in place branding and urban regeneration projects, which could add another dimension to the understanding of the relationships between these key concepts. Future researchers should also consider adding other areas to widen the scope of participants, in order to generate a more generalizable result in terms of sectoral representation for a country like the Philippines. An examination of the process could be further explored to provide more depth in the academic and practical discussions on place branding and urban regeneration. Further, researchers on the field could explore the premise of establishing a solid delineation between place branding and concepts like place promotion and marketing, particularly in the context of spatial development planning.

Given the importance of a place's cultural identity, the strategies to define and communicate such an identity are incredibly important to its sustainable viability. To this end, local development planning can help strengthen the dialectics of place branding and urban regeneration between key actors such as national and local governments. The goal in doing so should be to craft a responsive and practical policy that serves as a baseline for successful place branding and urban regeneration strategies.

Author Contributions: This study was conceived by all authors; methodology, C.N., and J.L.; formal analysis, C.N., and J.L.; investigation, C.N.; resources, C.N.; data curation, C.N.; writing-original draft preparation, C.N., and J.L.; writing - review and editing, C.N. and J.L.; supervision, J.L.; funding acquisition, J.L. All authors have read and agreed to the published version of the manuscript.

Funding: This research was supported by the Chung-Ang University Research Grants in 2019. This research was also supported by the National Research Foundation of Korea (NRF) grant funded by the Korea government (No. NRF-2019R1C1C1011089).

Conflicts of Interest: The authors declare no conflict of interest.

\section{References}

1. Kavaratzis, M.; Ashworth, G. Place marketing: How did we get here and where are we going? J. Place Manag. Dev. 2008, 1, 150-165. [CrossRef]

2. Ashworth, G.; Kavaratzis, M. Beyond the logo: Brand management for cities. J. Brand Manag. 2009, 16, 520-531. [CrossRef]

3. Lucarelli, A.; Brorström, S. Problematising place branding research: A meta-theoretical analysis of the literature. Mark. Rev. 2013, 13, 65-81. [CrossRef]

4. Moilanen, T.; Rainisto, S.K. How to Brand Nations, Cities, and Destinations; Palgrave Macmillan UK: London, UK, 2009.

5. Boisen, M.; Terlouw, K.; Groote, P.; Couwenberg, O. Reframing place promotion, place marketing, and place branding-moving beyond conceptual confusion. Cities 2018, 80, 4-11. [CrossRef]

6. Anholt, S. Anholt nation brands index: How does the world see America? J. Advert. Res. 2005, 45, $296-304$. [CrossRef]

7. Hanna, S.; Rowley, J. A practitioner-led strategic place brand-management model. J. Mark. Manag. 2013, 29, 1782-1815. [CrossRef]

8. Kokosalakis, C.; Bagnall, G.; Selby, M.; Burns, S. Place image and urban regeneration in Liverpool. Int. J. Consum. Stud. 2006, 30, 389-397. [CrossRef]

9. Muñiz Martinez, N. City marketing and place branding: A critical review of practice and academic research. J. Town City Manag. 2012, 2, 369-394.

10. Maheshwari, V.; Vandewalle, I.; Bamber, D. Place branding's role in sustainable development. J. Place Manag. Dev. 2011, 4, 198-213. [CrossRef]

11. Kavaratzis, M. From city marketing to city branding: Towards a theoretical framework for developing city brands. Place Brand. 2004, 1, 58-73. [CrossRef]

12. Kavaratzis, M. City marketing: The past, the present and some unresolved issues. Geogr. Compass 2007, 1, 695-712. [CrossRef] 
13. Paddison, R. City marketing, image reconstruction and urban regeneration. Urban Stud. 1993, 30, 339-349. [CrossRef]

14. Prilenska, V. City branding as a tool for urban regeneration: Towards a theoretical framework. Archit. Urban Plan. 2012, 6, 12-16. [CrossRef]

15. McCarthy, J. Regeneration of cultural quarters: Public art for place image or place identity? J. Urban Des. 2006, 11, 243-262. [CrossRef]

16. Colantonio, A.; Tim, D. Urban Regeneration and Social Sustainability: Best Practice from European Cities; John Wiley \& Sons: Hoboken, NJ, USA, 2011.

17. Clark, E. The Order and Simplicity of Gentrification: A Political Challenge; Routledge Taylor \& Francis Group: Oxfordshire, UK, 2005; pp. 261-269.

18. Dixon, T. The property development industry and sustainable urban brownfield regeneration in England: An analysis of case studies in Thames Gateway and Greater Manchester. Urban Stud. 2007, 44, 2379-2400. [CrossRef]

19. Slater, T. Gentrification of the city. In The New Blackwell Companion to the City; Wiley-Blackwell: Hoboken, NJ, USA, 2011; p. 1.

20. Czischke, D.; Moloney, C.; Turcu, C. Sustainable Regeneration in Urban Areas. Available online: https: //urbact.eu/sites/default/files/04_sustreg-web.pdf (accessed on 9 October 2019).

21. Chelleri, L.; Schuetze, T.; Salvati, L. Integrating resilience with urban sustainability in neglected neighborhoods: Challenges and opportunities of transitioning to decentralized water management in Mexico City. Habitat Int. 2015, 48, 122-130. [CrossRef]

22. Kavaratzis, M. Cities and their brands: Lessons from corporate branding. Place Branding Public Dipl. 2009, 5, 26-37. [CrossRef]

23. Kotler, P.; Gertner, D. A place marketing and place branding perspective revisited. Destin. Brands Manag. Place Reput. 2011, 3, 33-53.

24. Ashworth, G.J.; Kavaratzis, M.; Warnaby, G. The need to rethink place branding. In Rethinking Place Branding; Springer: Cham, Switzerland, 2015; pp. 1-11.

25. Acharya, A.; Rahman, Z. Place branding research: A thematic review and future research agenda. Int. Rev. Public Nonprofit Mark. 2016, 13, 289-317. [CrossRef]

26. da Silva Oliveira, E.H. Place Branding in Strategic Spatial Planning: An Analysis at the Regional Scale With Special Reference to Northern Portugal; University of Groningen: Groningen, The Netherlands, 2016.

27. Reuten, G. The status of Marx's reproduction schemes: Conventional or dialectical logic? In The Circulation of Capital; Palgrave Macmillan: London, UK, 1998; pp. 187-229.

28. PSA. All Regional Economies Grow in 2018. Philippine Statistics Authority. Available online: https: //psa.gov.ph/regional-accounts/grdp (accessed on 11 December 2019).

29. NEDA. Western Visayas Economy Grew by 6.1 Percent in 2018; National Economic and Development Authority-Region 6: Iloilo City, Philippines, 2018. Available online: http://nro6.neda.gov.ph/westernvisayas-economy-grew-by-6-1-percent-in-2018 (accessed on 11 December 2019).

30. Kavaratzis, M.; Ashworth, G.J. City branding: An effective assertion of identity or a transitory marketing trick? Tijdschr. Voor Econ. En Soc. Geogr. 2005, 96, 506-514. [CrossRef]

31. Saaty, T.L. Decision-making with the analytic hierarchy process. Int. J. Serv. Sci. 2008, 1, 83-98. [CrossRef]

32. Hildreth, J. The European City Brand Barometer-Revealing Which Cities Get the Brands They Deserve; Saffron Brand Consultants: London, UK, 2008; Volume 1, pp. 2-13.

33. Yoon, J. A Conceptual Model for City Branding Based on Semiotics. Ph.D. Thesis, Brunel University School of Engineering and Design, Uxbridge, England, 2010.

34. Trueman, M.; Cornelius, N. Hanging Baskets Or Basket Cases: Managing the Complexity of City Brands and Regeneration; University of Bradford, School of Management: Bradford, UK, 2006.

35. Rainisto, S.K. Success Factors of Place Marketing: A Study of Place Marketing Practices in Northern Europe and the United States; Helsinki University of Technology: Helsinki, Finland, 2003.

36. Zenker, S.; Beckmann, S.C. Measuring brand image effects of flagship projects for place brands: The case of Hamburg. J. Brand Manag. 2013, 20, 642-655. [CrossRef]

37. Golden, B.L.; Wang, Q. An alternate measure of consistency. In The Analytic Hierarchy Process; Springer: Berlin/Heidelberg, Germany, 1989; pp. 68-81. 
38. Wedley, W.C. Consistency prediction for incomplete AHP matrices. Math. Comput. Model. 1993, 17, $151-161$. [CrossRef]

39. Abbas, M.S.; Kocaoglu, D.F. Consistency Thresholds for Hierarchical Decision Model. In Proceedings of the Portland International Conference on Management of Engineering and Technology, Honolulu, HI, USA, 4-8 September 2016; IEEE: Piscatway, NJ, USA, 2016; pp. 566-575.

40. Kalandides, A. City marketing for Bogotá: A case study in integrated place branding. J. Place Manag. Dev. 2011, 4, 282-291. [CrossRef]

41. Kavaratzis, M. Place branding scholars and practitioners: "Strangers in the night?". J. Place Manag. Dev. 2015, 8, 266-270. [CrossRef]

42. Kotler, P. Marketing Management: A South Asian Perspective; Pearson Education: New Delhi, India, 2009.

43. Govers, R.; Go, F. Glocal, Virtual and Physical Identities, Constructed, Imagined and Experienced; Palgrave Macmillan: London, UK, 2009.

44. Evans, G. Hard-branding the cultural city-from Prado to Prada. Int. J. Urban Reg. Res. 2003, 27, 417-440. [CrossRef]

45. Greenberg, M. The limits of branding: The World Trade Center, fiscal crisis and the marketing of recovery. Int. J. Urban and Reg. Res. 2003, 27, 386-416. [CrossRef]

46. Hannigan, J. April Boom towns and cool cities: The perils and prospects of developing a distinctive urban brand in a global economy. In Proceedings of the Leverhulme International Symposium, London, UK, 19-21 April 2004; Taylor and Francis Online: Oxfordshire, UK, 2004; pp. 19-21.

47. Cleave, E.; Arku, G.; Sadler, R.; Gilliland, J. The role of place branding in local and regional economic development: Bridging the gap between policy and practicality. Reg. Stud. Reg. Sci. 2016, 3, 207-228. [CrossRef]

48. Republic Act 11201. An Act Creating the Department of Human Settlements and Urban Development, Defining Its Mandate, Powers and Function, and Appropriating Funds Thereof. Official Gazette. Available online: https:/www.officialgazette.gov.ph/downloads/2019/02feb/20190214-RA-11201-RRD.pdf (accessed on 9 October 2019).

(C) 2020 by the authors. Licensee MDPI, Basel, Switzerland. This article is an open access article distributed under the terms and conditions of the Creative Commons Attribution (CC BY) license (http://creativecommons.org/licenses/by/4.0/). 